\title{
Combine Effect of Metakaolin, Fly Ash and Steel Fiber on Mechanical Properties of High Strength Concrete
}

\author{
Vinod B. Shikhare ${ }^{1}$, L. G. Kalurkar ${ }^{2}$ \\ ${ }^{\text {I}}(P G$ Student, Department of Civil Engineering, MGM's Jawaharlal Nehru Engineering College, Aurangabad/ \\ Dr. B.A. Marathwada University, Aurangabad-431003, Maharashtra, India) \\ ${ }^{2}$ (Assistant Professor, Department of Civil Engineering, MGM's Jawaharlal Nehru Engineering College, \\ Aurangabad/ Dr. B.A. Marathwada University, Aurangabad-431003, Maharashtra India)
}

\begin{abstract}
In this experimental study the changes on some mechanical properties of concrete specimens produced by Metakaolin, fly Ash and steel fibers were investigated. The main objective of this work is to obtain a more ductile high strength concrete produced by using Metakaolin, Fly Ash and Steel Fiber. Three types of steel fibers were used in the experiments and volume fractions of steel fiber were $0.5 \%$ to $4.0 \%$. Addition of metakaolin and fly ash into the concrete were $5 \%$ and $10 \%$ by weight of cement content respectively. Water/cement ratio was 0.27. Compressive strength and split tensile strength tests were made on hardened concrete specimens. The use of metakaolin increased mechanical strength of concrete. On the other hand, the addition of steel fiber into concrete improves ductility of high strength concrete significantly.

Keywords-Compressive Strength, Fly Ash, High Strength Concrete (HSC), High Strength Fiber Reinforced Concrete (HSFRC), Metakaolin, Split Tensile Strength, Steel Fiber.

\section{INTRODUCTION}

The study of high strength concrete has become interesting when the concrete structures are growing taller and larger. High strength concrete is a type of high performance concrete with a specified compressive strength of $40 \mathrm{~N} / \mathrm{mm}^{2}$ or greater. Metakaolin, or heat-treated clay, may be used as a Supplementary Cementitious Material (SCM) in concrete to reduce cement consumption, to increase strength and the rate of strength gain, to decrease permeability, and to improve durability. Metakaolin reduces the porosity of concrete. Plain concrete possesses a very low tensile strength, limited ductility and little resistance to cracking. Internal micro cracks are inherently present in the concrete and its poor tensile strength is due to the propagation of such micro cracks, eventually leading to brittle fracture of the concrete. It has been recognized that the addition of small, closely spaced and uniformly dispersed fibers to the concrete would act as crack arrester and would substantially improve its compressive and flexural strength properties. This type of concrete is known as fiber reinforced concrete. Fiber reinforced concrete can be defined as composite material consisting of mixtures of cement, mortar or concrete and discontinuous, discrete, uniformly dispersed suitable fibers.
\end{abstract}

\section{MATERIAL USED}

\subsection{Cement}

Ordinary Portland Cement of 53 Grade conforming to IS: 12269-1987 was used in the investigation. The specific gravity of cement was 3.10.

\subsection{Coarse Aggregate}

Crushed stone metal with a maximum size of $12.5 \mathrm{~mm}$ from a local source having the specific gravity of 2.7 conforming to IS: $383-1970$ was used.

\subsection{Fine Aggregate}

Locally available river sand passing through $4.75 \mathrm{~mm}$ IS sieve conforming to grading zone-II of IS: 383-1970 was used. The specific gravity of fine aggregate was 2.54 .

\subsection{Metakaolin}

Metakaolin is not a byproduct. It is obtained by the calcinations of pure or refined Kaolinite clay at a temperature between $650^{\circ} \mathrm{C}$ and $850^{\circ} \mathrm{C}$, followed by grinding to achieve a fineness of $700-900 \mathrm{~m}^{2} / \mathrm{kg}$. Metakaolin is a high quality pozzolonic material, which is blended with cement in order to improve the durability of concrete. When used in concrete it will fill the void space between cement particles resulting in a more impermeable concrete. The physical properties and chemical composition of metakaolin are shown in table 2.1 and table 2.2 respectively. 
Table 2.1: Physical Properties of Metakaolin (www.metakaolin.com)

\begin{tabular}{|c|c|c|c|c|}
\hline Property & $\begin{array}{c}\text { Specific } \\
\text { Gravity }\end{array}$ & $\begin{array}{c}\text { Bulk Density } \\
\left(\mathrm{g} / \mathrm{cm}^{3}\right)\end{array}$ & $\begin{array}{c}\text { Physical } \\
\text { Form }\end{array}$ & Colour \\
\hline Value & 2.60 & 0.3 to 0.4 & Powder & Off White \\
\hline
\end{tabular}

Table 2.2: Chemical Composition of Metakaolin (www.metakaolin.com)

\begin{tabular}{|c|c|c|c|c|c|c|c|c|c|c|}
\hline Oxide & $\mathrm{SiO}_{2}$ & $\mathrm{AL}_{2} \mathrm{O}_{3}$ & $\mathrm{Fe}_{2} \mathrm{O}_{3}$ & $\mathrm{CaO}$ & $\mathrm{MgO}$ & $\mathrm{K}_{2} \mathrm{O}$ & $\mathrm{SO}_{3}$ & $\mathrm{TiO}_{2}$ & $\mathrm{Na}_{2} \mathrm{O}$ & L.O.I. \\
\hline \% by mass & 51.52 & 40.18 & 1.23 & 2.0 & 0.12 & 0.53 & 0.0 & 2.27 & 0.08 & 2.01 \\
\hline
\end{tabular}

\subsection{Fly Ash}

Fly ash is available in dry powder form and is procured from Dirk India Pvt. Ltd., Nasik. The light grey fly ash under the product name "Pozzocrete 83 " is available in $30 \mathrm{~kg}$ bags. The fly ash produced by the company satisfies all the requirements of the IS: 3812-1981.

\subsection{Super plasticizer}

Sulphonated Naphthalene formaldehyde condensate CONPLAST SP-430 super plasticizer obtained from Fosroc Chemicals (India) Pvt. Ltd. was used. It conforms to IS: 9103-1999 and has a specific gravity of 1.20 .

\subsection{Steel Fiber}

The main variables used in the study are three different types of steel fibers, i.e. Round Crimped Steel Fiber (RCSF), Hook Ended Steel Fiber (HESF) and Flat Crimped Steel Fiber (FCSF) with different dosages of fibers are used by weight of cementitious material. The properties of steel fibers are shown in table 2.3.

Table 2.3: Properties of Steel Fiber used

\begin{tabular}{|c|c|c|c|}
\hline Type & Length L $(\mathbf{m m})$ & Diameter d $(\mathbf{m m})$ & Aspect Ratio $(\mathbf{L} / \mathbf{d})$ \\
\hline RCSF & 25 & 0.55 & 45 \\
\hline FCSF & 30 & $2 \mathrm{~mm}$ thick & 15 \\
\hline HESF & 25 & 0.55 & 45 \\
\hline
\end{tabular}

\subsection{Water}

Fresh portable water which is free from concentration of acid and organic substances is used for mixing the concrete and curing.

\section{Mixture Proportion ANd SPECIMEN Preparation}

The experimental investigation was carried out to study the properties of high strength concrete of M70 grade which was design by British DoE method. Metakaolin was added as $5 \%$ weight of cementitious material and fly is by $10 \%$ weight of cementitious material. There are three types of steel fibers are used in this investigation, i.e. Round Crimped Steel Fiber (RCSF), Hook Ended Steel Fiber (HESF) and Flat Crimped Steel Fiber (FCSF) with different dosages of fibers are used by $0.5 \%, 1 \%, 1.5 \%, 2 \%, 2.5 \%, 3 \%, 3.5 \%$ and $4 \%$ weight of cementitious material. Table 3.1 shows the mixtures used and their compositional contents.

Table 3.1: Mix Proportion

\begin{tabular}{|c|l|c|}
\hline Sr. No & \multicolumn{1}{|c|}{ Material } & Mass \\
\hline 1 & Cementitious Material & $556 \mathrm{Kg} / \mathrm{M}^{3}$ \\
\hline 2 & Ordinary Portland Cement $(85 \%$ Of CM) & $472.6 \mathrm{Kg} / \mathrm{M}^{3}$ \\
\hline 3 & Metakaolin (5\% Of CM) & $27.8 \mathrm{Kg} / \mathrm{M}^{3}$ \\
\hline 4 & Fly Ash (10\% Of CM) & $55.6 \mathrm{Kg} / \mathrm{M}^{3}$ \\
\hline 5 & Fine Aggregate & $702 \mathrm{Kg} / \mathrm{M}^{3}$ \\
\hline 6 & Coarse Aggregate & $1042 \mathrm{Kg} / \mathrm{M}^{3}$ \\
\hline 7 & Water & $150 \mathrm{Kg} / \mathrm{M}^{3}$ \\
\hline 8 & Superplasticizer (CONPLAST SP-430) & $18 \mathrm{Ml} \mathrm{Per} \mathrm{Kg} \mathrm{Of} \mathrm{Cement}$ \\
\hline 9 & Water Binder Ratio & 0.27 \\
\hline
\end{tabular}

IV. METHODOLOGY

For compressive strength test, cube specimens of dimensions (100 mm x $100 \mathrm{~mm} \times 100 \mathrm{~mm})$ were cast. The specimens were demoulded after 24 hours of casting and were transferred to curing tank for 28 days. The compressive strength of concrete was determined in accordance with Indian Standards IS: 516-1959. The result obtained are shown in Table 4.1 
Table 4.1: Compressive Strength at 28 Days

\begin{tabular}{|c|c|c|c|c|}
\hline \multirow{2}{*}{$\begin{array}{c}\text { Sr. } \\
\text { No }\end{array}$} & $\begin{array}{c}\text { Fiber Volume } \\
\text { Fraction } \\
\text { V } \boldsymbol{f}(\boldsymbol{\%})\end{array}$ & \multicolumn{3}{|c|}{$\begin{array}{c}\text { Compressive Strength At 28 Days } \\
\left(\mathbf{N} / \mathbf{m m}^{2}\right)\end{array}$} \\
\cline { 3 - 5 } & 0 & RCSF & FCSF & HESF \\
\hline 1 & 0.5 & 75.30 & 75.30 & 75.30 \\
\hline 2 & 1.0 & 79.85 & 78.40 & 76.50 \\
\hline 3 & 1.5 & 83.25 & 79.80 & 77.85 \\
\hline 4 & 2.0 & 86.50 & 81.25 & 79.38 \\
\hline 5 & 2.5 & 87.30 & 82.75 & 79.85 \\
\hline 6 & 3.0 & 88.50 & 85.50 & 80.85 \\
\hline 7 & 3.5 & 89.40 & 86.85 & 81.60 \\
\hline 8 & 4.0 & 87.65 & 84.80 & 83.55 \\
\hline 9 & & & & \\
\hline
\end{tabular}

\subsection{Split Tensile Strength}

For split tensile strength test, cylinder specimens of dimensions $(150 \mathrm{~mm} \times 300 \mathrm{~mm})$ were cast. The specimens were demoulded after 24 hours of casting and were transferred to curing tank for 28 days. These specimens were tested under Universal Testing Machine. In each category three cylinders were tested and their average value is reported. The split tensile strength of concrete was determined in accordance with Indian Standards IS: 5816-1999. Split tensile strength was calculated as: Split Tensile strength $\left(\mathrm{N} / \mathrm{mm}^{2}\right)=2 \mathrm{P} / \pi \mathrm{DL}$, where $\mathrm{P}=$ failure load, $\mathrm{D}=$ diameter of cylinder, $\mathrm{L}=$ Length of cylinder. The result obtained are shown in Table 4.2

Table 4.2: Split Tensile Strength at 28 Days

\begin{tabular}{|c|c|c|c|c|}
\hline \multirow{2}{*}{$\begin{array}{c}\text { Sr. } \\
\text { No }\end{array}$} & $\begin{array}{c}\text { Fiber Volume } \\
\text { Fraction } \\
\text { V } \boldsymbol{f ( \% )}\end{array}$ & \multicolumn{3}{|c|}{$\begin{array}{c}\text { Split Tensile Strength At 28 Days } \\
\left(\mathbf{N} / \mathbf{m m}^{2}\right)\end{array}$} \\
\cline { 3 - 5 } & 0 & $\mathbf{R C S F}$ & $\mathbf{F C S F}$ & HESF \\
\hline 1 & 0.5 & 3.26 & 3.26 & 3.26 \\
\hline 2 & 3.30 & 3.38 & 3.27 \\
\hline 3 & 1.0 & 3.40 & 3.45 & 3.32 \\
\hline 4 & 1.5 & 3.45 & 3.53 & 3.40 \\
\hline 5 & 2.0 & 3.52 & 3.60 & 3.45 \\
\hline 6 & 2.5 & 3.59 & 3.65 & 3.50 \\
\hline 7 & 3.0 & 3.68 & 3.72 & 3.60 \\
\hline 8 & 3.5 & 3.72 & 3.79 & 3.65 \\
\hline 9 & 4.0 & 3.67 & 3.73 & 3.63 \\
\hline
\end{tabular}

\section{RESULT AND DISCUSSION}

\subsection{Effect of fiber volume fraction $\mathrm{V} f(\%)$ on Compressive Strength of High Strength Concrete}

The compressive strength increases significantly due to the addition of steel fiber compared with normal concrete. In general, the compressive strength of the concrete having Round Crimped Steel Fiber (RCSF) was higher than that of concrete with Flat Crimped Steel Fiber (FCSF) and Hook Ended Steel Fiber (HESF) at the same volume fractions of steel up to the limit. The compressive strength of concrete with steel fiber is increased up to the $3.5 \%$ of fiber volume fraction and then decreases. The maximum values of compressive strength at $3.5 \%$ fiber volume fraction are $89.40 \mathrm{~N} / \mathrm{mm}^{2}, 86.85 \mathrm{~N} / \mathrm{mm}^{2}$ and $83.55 \mathrm{~N} / \mathrm{mm}^{2}$ for RCSF, FCSF and HESF respectively. The effect of metakaolin, fly ash and steel fiber on compressive strength of concrete shown in figure 5.1.

\subsection{Effect of fiber volume fraction $\mathrm{V} f(\%)$ on Split Tensile Strength of High Strength Concrete}

The result from Table 4.2 shows that the cylinder split tensile strength of concrete increases considerably with an increase in fiber content. A continuous increase in strength is observed up to a limit. The $3.5 \%$ of fiber content has given maximum increase in split tensile strength as compared to that of normal concrete. The Flat Crimped Steel Fiber (FCSF) gives maximum split tensile strength than that of Round Crimped Steel Fiber (RCSF) and Hook Ended Steel Fiber (HESF).The effect of metakaolin, fly ash and steel fiber on split tensile strength of concrete shown in figure 5.2. 


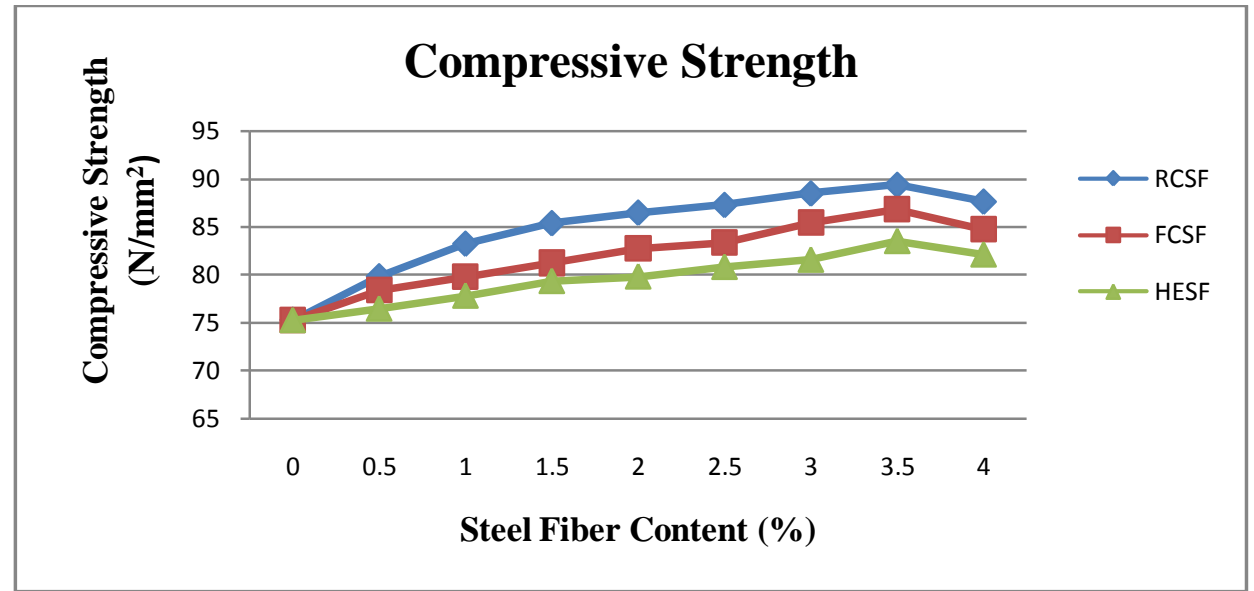

Fig. 5.1 Compressive Strength of concrete with percentage variation of Steel Fibers

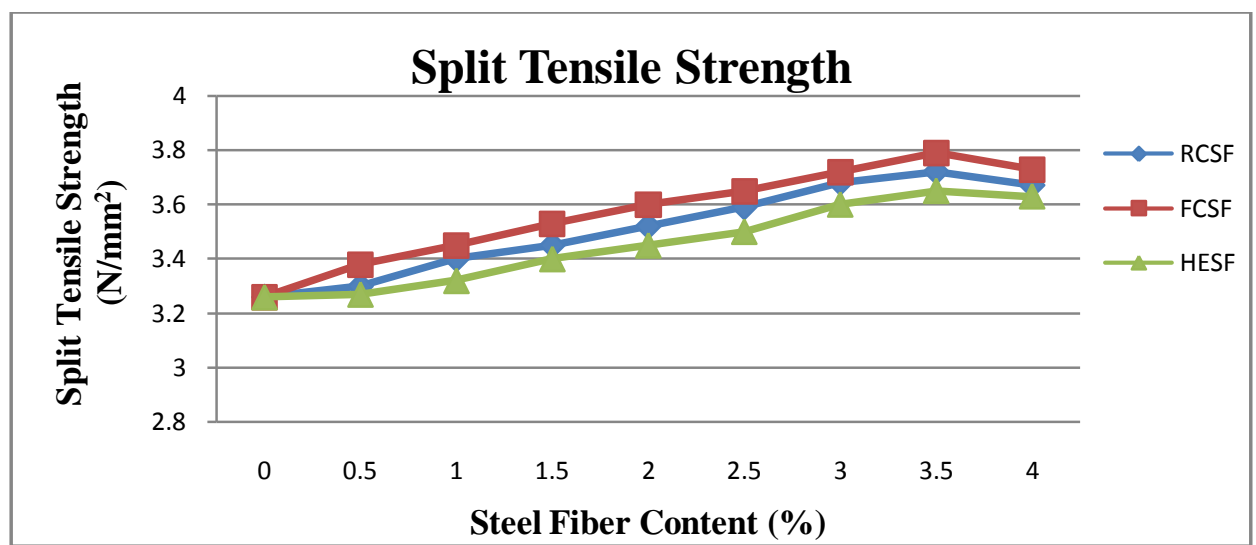

Fig. 5.2 Split Tensile Strength of concrete with percentage variation of Steel Fibers

\section{Conclusion}

Plain concrete is a brittle material and fails suddenly. Addition of steel fibers to concrete changes its brittle mode of failure into a more ductile one and improves the concrete ductility. The compressive strength and split tensile strength of concrete increasing with fiber content. The maximum value of compressive strength gives the RCSF and split tensile strength gives FCSF at $3.5 \%$ fiber content.

\section{REFERENCES}

[1] Chitlange M. R., Bang, R. S., Pajgade P. S., "Strength appraisal of artificial sand as a fine aggregate in steel fiber reinforced concrete (SFRC)",ARPN Journal of Engineering and Applied Sciences, Vol.5,No.10,October 2010,pp.34-38.

[2] Sabir B.B., Wild S. BaiJ. "Metakaolin and calcined clays as pozzolans for concrete: a review", Cement and concrete research, 23(2001), pp.441-454.

[3] Dr. P. Srinivasa Rao, Dr. Sravana, Dr. Z. Abdul Rahim and Dr. T. Seshadri Sekhar, "Durability Studies on Steel Fiber Reinforced Metakaolin Blended Concrete", AKGEJC International Journal of Technology, Vol. 3, No.1, pp.38-43.

[4] J. Bai, S. Wild, B. B. Sabir and J. M. Kinuthia, "Strength development in concrete incorporating PFA and Metakaolin", Magazine of concrete research, 52, 2000, pp.-153-162.

[5] Dasari Venkateswara Reddy and Prashant Y. Pawade, "Combine effect of silica fume and steel fiber on mechanical properties on standard grade of concrete and their interrelations", International Journal of Advanced Engineering Technology, Vol.III, Issue I, January-March, 2012, pp.-361-366.

[6] Dr. P. Srinivasa Rao, Dr. Sravana, Dr. Z. Abdul Rahim, Dr. T. Seshadri Sekhar and Dr. P. Aarathi, "Cracking Behavior of Metakaolin blended high strength concrete in flexure by using crimped steel fibers", Journal of Civil Engineering Science: An International Journal, Vol.1, No.1-2, January-December,2012,pp.-15-24.

[7] IS: 456-2000, "Indian Standard for code of practice for plain and reinforced concrete".

[8] IS: 12269-1989, "Indian Standard Specification for 53 Grade Ordinary Portland Cement".

[9] IS: 383-1970, "Specification for course and Fine Aggregates from natural sources for concrete." Bureau of Indian standards, New Delhi.

[10] IS: 516-1959, Edition 1.2 (1991-07), "Indian Standard for Methods of test for strength of concrete.

[11] Sadr Momtazi A, Ranjbar M. M., Balalaei F, Nemati R, "The effect of Iran's Metakaolin in enhancing the concrete compressive strength", Cement and Concrete Research,pp.-1-7.

[12] IS: 5816-1999, "Splitting Tensile Strength of Concrete-Method of Test (First Revision)". 